\title{
EPMAによる $\mathrm{Fe}^{2+} / \mathrm{Fe}^{3+}$ おび $\mathrm{Mn}^{2+} / \mathrm{Mn}^{3+}$ 比の見積もり
}

\author{
木村佳央* ·赤坂正秀*
}

\author{
Estimation of $\mathrm{Fe}^{2+} / \mathrm{Fe}^{3+}$ and $\mathrm{Mn}^{2+} / \mathrm{Mn}^{3+}$ Ratios by Electron Probe Micro Analyzer
}

\author{
Yoshio KIMURA $^{*}$ and Masahide AKASAKA*
}

\begin{abstract}
We have reinvestigated the relationship between the relative intensities of $\mathrm{L}_{\alpha}$ and $\mathrm{L}_{\beta} \mathrm{X}$-ray emission peaks, $\left[\mathrm{L}_{\beta}\right.$ / $\mathrm{L}_{\alpha}$ ], and $\mathrm{Fe}^{2+} / \mathrm{Fe}^{3+}$ or $\mathrm{Mn}^{2+} / \mathrm{Mn}^{3+}$-ratios in silicate minerals. For Fe-bearing silicates, two kinds of regression lines were obtained; (1) $0 \leq\left[\mathrm{Fe}^{2+} /\left(\mathrm{Fe}^{2+}+\mathrm{Fe}^{3+}\right)\right] \leq 0.74:\left[\mathrm{L}_{\beta} / \mathrm{L}_{\alpha}\right]_{\mathrm{Fe}}=0.1414 \times\left[\mathrm{Fe}^{2+} /\left(\mathrm{Fe}^{2+}+\mathrm{Fe}^{3+}\right)\right]+0.4121\left(\mathrm{R}^{2}=0.986\right)$, (2) 0.74 $\leq$ $\left[\mathrm{Fe}^{2+} /\left(\mathrm{Fe}^{2+}+\mathrm{Fe}^{3+}\right)\right] \leq 1.00:\left[\mathrm{L}_{\beta} / \mathrm{L}_{\alpha}\right]_{\mathrm{Fe}}=0.8024 \times\left[\mathrm{Fe}^{2+} /\left(\mathrm{Fe}^{2+}+\mathrm{Fe}^{3+}\right)\right]-0.0798\left(\mathrm{R}^{2}=0.973\right)$. By using these regression lines, it is possible to estimate semiquantitative $\mathrm{Fe}^{2+} /\left(\mathrm{Fe}^{2+}+\mathrm{Fe}^{3+}\right)$-ratio of $\mathrm{Fe}$-silicates containing total $\mathrm{FeO}$ more than 5 wt.\%. For Mn-bearing silicates, a regression line of $\left[\mathrm{L}_{\beta} / \mathrm{L}_{\alpha}\right]_{\mathrm{Mn}}=0.46 \times\left[\mathrm{Mn}^{2+}\left(\mathrm{Mn}^{2+}+\mathrm{Mn}^{3+}\right)\right]+0.554\left(\mathrm{R}^{2}=0.968\right)$ was obtained. However, even if samples contain total $\mathrm{MnO}$ more than $10 \mathrm{wt} . \%$, standard deviation of $\left[\mathrm{L}_{\beta} / \mathrm{L}_{\alpha}\right]_{\mathrm{Mn}}$-ratio for each sample is large. Thus, $\left[\mathrm{L}_{\beta} / \mathrm{L}_{\alpha}\right]_{\mathrm{Mn}}$-ratio can not be used for semiquantitative determination of $\mathrm{Mn}^{2+} /\left(\mathrm{Mn}^{2+}+\mathrm{Mn}^{3+}\right)$-ratio but gives us qualitative information.
\end{abstract}

\section{1.はじめに}

鉱物中の遷移金属元素の酸化数は鉱物の生成条件によ って変化する．遷移元素は酸化数の違いによって結晶化 学的挙動が異なり, 鉱物の物理的性質は鉱物中の遷移元 素の酸化数によって変化する. 特に鉄とマンガンは地壳 存在量も多く, 主要鉱物の主成分であり, それらの酸化 数を知ることは, 鉱物の生成条件を推定したり物理的性 質を理解する上で重要である.

筆者らは鉄の酸化数を決定するために, メスバウアー 分光法を用いているが, 純粋な試料を必要量分離するの に時間がかかったり，それが不可能な場合もある。鉱物 としては 1 相でも，化学組成が不均質な場合もある．鉱 物中のマンガンの酸化数がひとつでない場合には, その 酸化数や存在量の決定は鉄の場合よりもさらに困難であ る.このように，遷移元素の酸化数の決定はただでさえ

1999年 6 月 1 日受理

* 島根大学総合理工学部地球資源環境学科

Department of Geoscience, Shimane University, 1060 Nishikawatsu, Matsue 690-8504, Japan
面倒であるが，筆者らはこの数年間，鉄とマンガンの両 方を含み, かつ, 生成温度が低いために微細で化学組成 的に不均質であるパンペリー石族鉱物の鉄とマンガンの 酸化数と席選択性を検討してきた(Togari and Akasaka, 19871) ; Togari et al., 19882) ; 木村ほか, 19963) ; Akasaka et al., 19974) $)$. これらの研究ではEPMA分析, メスバウ アー分光分析，示差熱分析を行って間接的にマンガンの 酸化数を求めたが, 試料の均質性, 複数の方法を用いる ことによる誤差などの問題もあり，クロスチェックする 方法を検討してきた。

Albee and Chodos $(1970)^{5)}$ は特性 $\mathrm{X}$ 線の $\mathrm{L}_{\alpha}$ 線と $\mathrm{L}_{\beta}$ 線の強 度が $\mathrm{Fe}^{2+} / \mathrm{Fe}^{3+}$ 比, $\mathrm{Mn}^{2+} / \mathrm{Mn}^{3+}$ 比と相関関係を示すことを 利用し, EPMAによって珪酸塩鉱物および酸化物中の $\mathrm{Fe}^{2+}, \mathrm{Fe}^{3+}$ およ゙ $\mathrm{Mn}^{2+}, \mathrm{Mn}^{3+}$ の半定量分析が可能であるこ とを示唆した. Smith and O'Nions (1971) 6)およびO'Nions and Smith $(1971)^{7)}$ は, 鉄酸化物について同様の検討を行 い, $\mathrm{Fe}$ の酸化数と $\left[\mathrm{L}_{\beta} / \mathrm{L}_{\alpha}\right]_{\mathrm{Fe}}$ 比の間の相関を理論的に説 明したが, X線強度比が加速電圧や取り出し角度によっ て大きく変化することなどから，定性的なことしか言え ないであろうと述へ，この方法の定量的実用性に疑問を 
Table 1 Chemical compositions of standard minerals.

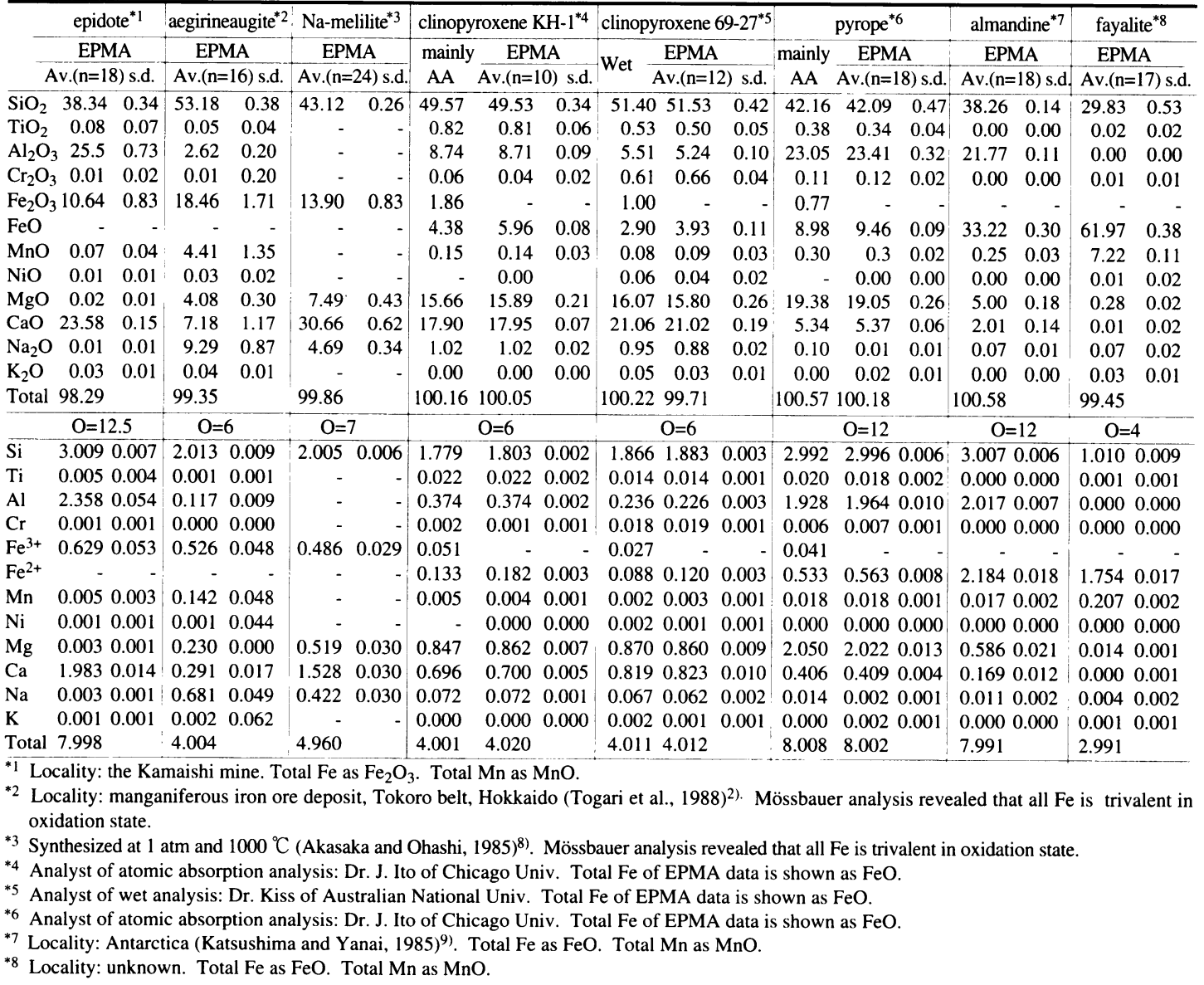

呈した.しかし同時に, 彼らは, その後の研究によって 半定量的情報を得られるかもしれないと含みを残してい る. EPMA分析によって, 微細鉱物や不均質な鉱物の局 所部の $\mathrm{Fe}^{2+} / \mathrm{Fe}^{3+}$ 比, $\mathrm{Mn}^{2+} / \mathrm{Mn}^{3+}$ 比について手がかりが得 られるのであれば, 理論的説明や厳密な定量分析は困難 だとしても魅力的な方法である。そこで筆者らはAlbee and Chodos $(1970)^{5) の}$ 方法を，ケイ酸塩鉱物および鉄酸化 物について追試した。この際, Albee and Chodos (1970) $)^{5)}$ の方法にいくつか工夫をした. 本論では, 著者らの行っ た測定方法とケイ酸塩鉱物に関する結果の一部を紹介し たい.

\section{2. 実験方法}

使用した標準試料をTable 1 に示す． $\mathrm{Fe}^{3+}$-ケイ酸塩鉱 物の標準試料のうち, エジリンオージャイト(北海道常 呂带含マンガン鉄鉱床産 ; Togari et al., 1988)2), 合成Naメリライト (Akasaka and Ohashi, 1985)
析およびメスバウアー分光分析が行われており，すべて

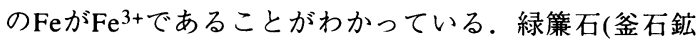
山新山鉱床産)についてはメスバウアー法による検討が なされていないが, 構造式で判断する限りすべてのFeを 3 価とみなして差し支えない. $\mathrm{Fe}^{2+}$ と $\mathrm{Fe}^{3+を}$ 含むケイ酸 塩鉱物として，パイロープおよび 2 種類の単斜輝石 KH1と69-27を用いた。これらは湿式分析によって $\mathrm{Fe}^{2+}$ $\mathrm{Fe}^{3+}$ が定量されている(パイロープ：J. Ito，未公表データ ; 単斜輝石KH-1：J. Ito，未公表デー夕；単斜輝石69-27： Kiss，未公表データ). $\mathrm{Fe}^{2+}$ ケケイ酸塩鉱物として用いた アルマンディン(南極Ytrehovdeholmen島のgarnet gneiss 産; Katsushima and Yanai,1984)9), ファヤライト(産地不 明)に関しては，構造式で判定するかぎりすべてのFeを $\mathrm{Fe}^{2+}$ とみなして良い。

含マンガンケイ酸塩鉱物の標準試料については, $\mathrm{Mn}^{3+}$ のを含む鉱物として常呂帯マンガン鉄鉱床産紅 策石(Akasaka et al., 1988) ${ }^{10)}$ と合成のSr紅策石(鈴木ほか, 
Table 1 (Continued)

\begin{tabular}{|c|c|c|c|c|c|c|c|c|c|c|c|}
\hline & \multicolumn{2}{|c|}{ piemontite $^{* 9}$} & \multicolumn{2}{|c|}{ Sr-piemontite ${ }^{* 10}$} & \multicolumn{2}{|c|}{ spessartine $^{* 11}$} & \multicolumn{2}{|c|}{ rhodonite $^{* 11}$} & \multicolumn{2}{|c|}{ pyroxmangite ${ }^{* 11}$} & tephroite $^{* 11}$ \\
\hline & \multicolumn{2}{|c|}{ EPMA } & \multicolumn{2}{|c|}{ EPMA } & \multicolumn{2}{|c|}{ EPMA } & \multicolumn{2}{|c|}{ EPMA } & \multicolumn{2}{|c|}{ EPMA } & EPMA \\
\hline & \multicolumn{2}{|c|}{ Av. $(n=15)$ s.d. } & \multicolumn{2}{|c|}{ Av. $(n=23)$ s.d. } & \multicolumn{2}{|c|}{ Av. $(n=11)$ s.d. } & \multicolumn{2}{|c|}{ Av. $(n=5)$ s.d. } & \multicolumn{2}{|c|}{ Av. $(n=15)$ s.d. } & Av. $(n=7)$ s.d. \\
\hline $\mathrm{SiO}_{2}$ & 35.89 & 0.22 & 36.37 & 0.94 & 36.72 & 0.24 & 47.04 & $0 . \overline{33}$ & 46.88 & 0.20 & $30.57 \quad 0.46$ \\
\hline $\mathrm{TiO}_{2}$ & 0.06 & 0.04 & 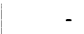 & - & 0.30 & 0.12 & 0.01 & 0.02 & 0.01 & 0.02 & $0.03 \quad 0.03$ \\
\hline $\mathrm{l}_{2} \mathrm{O}_{3}$ & 17.83 & 0.53 & 18.99 & 2.22 & 20.57 & 0.17 & 0.01 & 0.01 & 0.01 & & $0.00 \quad 0.00$ \\
\hline $\mathrm{r}_{2} \mathrm{O}_{3}$ & 0.00 & 0.00 & - & - & 0.00 & 0.00 & 0.00 & 0.00 & 0.00 & 0.00 & $0.01 \quad 0.02$ \\
\hline${ }_{2} \mathrm{O}_{3}$ & .08 & 0.03 & . & - & 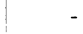 & - & - & & - & - & - \\
\hline $\mathrm{Fe}_{2} \mathrm{O}_{3}$ & 3.37 & 0.67 & . & - & - & - & - & & - & - & - \\
\hline $\mathrm{Mn}_{2} \mathrm{O}_{3}$ & 315.95 & 0.72 & 17.90 & 2.40 & - & - & - & & - & - & - \\
\hline $\mathrm{FeO}$ & - & - & - & - & 12.23 & 2.98 & 0.67 & 0.11 & 6.17 & & $\begin{array}{ll}15.64 & 0.44\end{array}$ \\
\hline $\mathrm{InO}$ & - & - & - & - & 26.32 & 2.04 & 48.28 & 1.69 & 42.60 & & $\begin{array}{ll}50.39 & 0.71\end{array}$ \\
\hline 0 & 0.01 & 0.02 & - & - & 0.01 & 0.00 & 0.03 & 0.02 & 0.01 & 1 & $0.01 \quad 0.02$ \\
\hline $\mathrm{O}$ & 6 & 0.06 & - & - & 0.24 & & 0.81 & 0.22 & 0.85 & & $3.21 \quad 0.12$ \\
\hline $\mathrm{aO}$ & 22.23 & 0.16 & 17.98 & 2.68 & 4.27 & 0.51 & 3.49 & 1.51 & 3.74 & 0.54 & $0.24 \quad 0.08$ \\
\hline & - & - & 6.16 & 2.90 & - & - & - & & - & - & - \\
\hline $\mathrm{a}_{2} \mathrm{O}$ & 03 & 0.02 & - & - & 0.00 & 0.00 & 0.00 & 0.00 & 0.01 & & $0.00 \quad 0.00$ \\
\hline $\mathrm{K}_{2} \mathrm{O}$ & 0.03 & 0.01 & - & - & 0.03 & 0.01 & 0.04 & 0.01 & 0.04 & 0.01 & $0.03 \quad 0.01$ \\
\hline Total & 95.65 & & 97.40 & & 100.69 & & 100.39 & & 100.31 & & 100.13 \\
\hline & $\mathrm{O}=12$ & & $\mathrm{O}=$ & 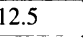 & $\mathrm{O}=12$ & & $\mathrm{O}=15$ & & $\mathrm{O}=2$ & & $\mathrm{O}=4$ \\
\hline $\mathrm{Si}$ & 2.998 & 009 & 039 & 051 & 2.983 & 10 & 5.017 & 0.007 & 7.014 & & 1.0020 .010 \\
\hline 1 & 04 & 0.003 & - & & 0.018 & 0.007 & 0. & 0.002 & 0.002 & 0. & 0.001 \\
\hline & & 0.049 & 69 & 0.206 & 1.969 & 0.012 & 0.0 & 0.001 & 0.002 & 0. & 0.000 \\
\hline 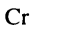 & 000 & 0.000 & - & - & 0.000 & 0.000 & 0.000 & 0.000 & 0.000 & 0.000 & 0.0000 .000 \\
\hline V & 06 & 0.002 & - & - & 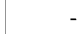 & - & - & & - & - & - \\
\hline$\Gamma$ & 12 & 0.042 & - & - & 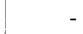 & - & - & & - & - & - \\
\hline $\mathrm{Mn}^{3+}$ & 1.014 & 0.046 & 1.140 & 0.164 & - & - & - & - & - & - & - \\
\hline $\mathrm{Fe}^{2+}$ & - & - & - & - & 32 & & 6 & 009 & 72 & & 240.015 \\
\hline $\mathrm{Mn}^{2+}$ & - & - & - & - & 10 & & 5 & 0.049 & & & 1.4030 .022 \\
\hline & 01 & & - & - & 0.001 & 0.001 & 0 & 0.002 & 0.001 & 0. & 0.0000 .001 \\
\hline & 0.020 & 0.007 & - & - & 0.029 & 0.014 & 0.130 & 0.034 & 0.190 & 0.025 & 0.1570 .006 \\
\hline $\mathrm{Ca}$ & 1.990 & 0.013 & 08 & 0.227 & 0.371 & 0.043 & 0.323 & 0.016 & 0.600 & 0.087 & 0.0090 .003 \\
\hline $\mathrm{Sr}$ & 0.000 & 0.000 & 299 & 0.128 & - & - & - & & - & - & - \\
\hline $\mathrm{Na}$ & 0.005 & 0.003 & - & - & 00 & & 00 & 0.000 & 0.002 & & 0.0000 .000 \\
\hline $\mathrm{K}$ & 0.003 & 0.001 & - & - & 0.003 & 0.001 & 0.006 & 0.001 & 0.007 & 0.002 & 0.0010 .001 \\
\hline Total & 8.009 & & 7.956 & & 8.016 & & 9.985 & & 13.998 & & 2.997 \\
\hline
\end{tabular}

${ }^{* 9}$ Locality: manganiferous iron ore deposit, Tokoro belt, Hokkaido (Akasaka et al., 1988) ${ }^{10)}$.

Total $\mathrm{Mn}$ as $\mathrm{Mn}_{2} \mathrm{O}_{3}$. Total $\mathrm{Fe}$ as $\mathrm{Fe}_{2} \mathrm{O}_{3}$.

${ }^{*} 10$ Synthesized at $300 \mathrm{MPa}$ and $550^{\circ} \mathrm{C}$ (Suzuki et al., 1996) ${ }^{11)}$. Total $\mathrm{Mn}$ as $\mathrm{Mn}_{2} \mathrm{O}_{3}$.

${ }^{*} 11$ Locality: manganese ore deposit, Tottori Prefecture (Watanabe and Akasaka, 1995) ${ }^{12}$ ) Total $\mathrm{Mn}$ as $\mathrm{MnO}$. Total Fe as FeO.
径R(JEOL分光器ではR=140 mm), 分光結晶の面間隔 $\mathrm{d}(\AA)$, 特性X 線の波長 $\lambda(\AA)$, 反射の次数 $\mathrm{n}$ の間 $に \mathrm{~L}=(\mathrm{R} / \mathrm{d}) \times \mathrm{n} \lambda$ の関係がある．測 定したスペクトルを最小二乗法 でカーブフィッティングし，強 度の読み取りに人為的誤差が入 るのを防いだ。各分析点につい て 5 回測定し, 最大値と最小值 を除いた 3 つ測定值の平均値 を測定点の $\mathrm{L}_{\beta} / \mathrm{L}_{\alpha}$ 比とした。

\section{3. 結 果}

\section{3. $1 \mathrm{Fe}^{2+} /\left(\mathrm{Fe}^{2+}+\mathrm{Fe}^{3+}\right)$ 比と $\left[\mathrm{L}_{\beta} / L_{\alpha}\right] \mathrm{Fe}$ 比の関係}

Fig. 1およびTable 2 Aにスペク トルとフィッティングした結果 を示す. Albee and Chodos (1970) ${ }^{5)}$ は $\mathrm{L}_{\alpha}, \mathrm{L}_{\beta}$ 線のみからなるスペクト ルを示しているが，著者らの測 定では分光結晶TAPのL值が189 $\mathrm{mm}$ 付近にFe $\mathrm{K}_{\alpha}$ 線の弱いピークが 認められる。しかし， $\mathrm{L}_{\alpha}$ および $\mathrm{L}_{\beta}$ 線の強度に大きな影響を及ほ すほどではないので， $\mathrm{L}_{\alpha}$ およ゙ $\mathrm{L}_{\beta}$ 線のみでフィッティングした. エジリンオージャイト, 合成 $\mathrm{Na}$ メリライト, 緑策石の平均 total $\mathrm{Fe}_{2} \mathrm{O}_{3}$ はそれぞれ18.5, 13.9, 10.6 wt.\%であるが, それらの $\left[\mathrm{L}_{\beta} / \mathrm{L}_{\alpha}\right]$ 1996) ${ }^{11)}, \mathrm{Mn}^{2+}$ みを含む鉱物として鳥取県のマンガン 鉱床産のテフロアイト, パイロキシマンジャイト, ロー

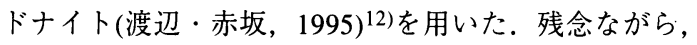
$\mathrm{Mn}^{2+}$ と $\mathrm{Mn}^{3+}$ 両方を適量含む試料は準備できなかった。

EPMAはJEOL JXA-8800Mで, 分光結晶はTAPを用い た. Albee and Chodos (1970)5)は, 電子線による試料のダ メージが少ない測定条件の設定を喚起しているが, 予察 的な測定の結果, 加速電圧が $15 \mathrm{kV}$, PCD電流が $3.0 \times 10^{-8}$ A，ビーム径が5から $10 \mu \mathrm{m}$ であればほぼ適当な条件であ ると判断された.

$\mathrm{Fe} \mathrm{L}_{\alpha}$ 線， $\mathrm{L}_{\beta}$ 線についてはTAPのL值が186 mmから 193 $\mathrm{mm}$ まで, Mnについては206 mm から $213 \mathrm{~mm}$ までの範囲を, ステップ間隔 $0.05 \mathrm{~mm}, 1$ ステップあたりの測定時間を 10 秒で強度の測定を行った. なお, 分光結晶のL值はX線 発生点から分光結晶までの距離であり, ローランド円半
比は $0.40 \pm 0.01,0.41 \pm 0.03,0.42 \pm 0.01$ である. Albee and Chodos $(1970)^{5)}$ は，4配位席にFe ${ }^{3+を}$ 含む合成Feマイクロ クリンの $\left[\mathrm{L}_{\beta} / \mathrm{L}_{\alpha}\right]_{\mathrm{Fe}}$ 比が6配位席に $\mathrm{Fe}^{3+を}$ 含む合成エジリ ンの $\left[\mathrm{L}_{\beta} / \mathrm{L}_{\alpha}\right]_{\mathrm{Fe}}$ 比より高いと述べている，しかし，筆者ら

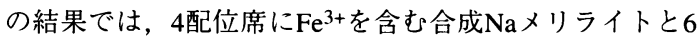

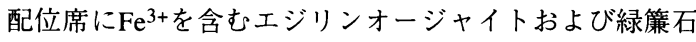
の $\left[\mathrm{L}_{\beta} / \mathrm{L}_{\alpha}\right]_{\mathrm{Fe}}$ 比は誤差内でほぼ一致しており，配位席の違 いによる $\left[\mathrm{L}_{\beta} / \mathrm{L}_{\alpha}\right]_{\mathrm{Fe}}$ 比の変化は認められなかった．アルマ ンディンおよびファヤライトの平均 total $\mathrm{FeO}$ はそれぞれ 33.2 お び 42.0 wt.\%であるが, $\left[\mathrm{L}_{\beta} / \mathrm{L}_{\alpha}\right]$ 比はそれぞれ 0.74

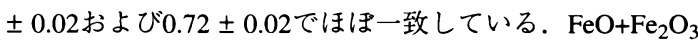
含有量がそれぞれ約 9 wt.\%および6 wt.\%である単斜輝石 $\mathrm{KH} 1$ およびパイロープは良好なスペクトルであるが, $\mathrm{FeO}+\mathrm{Fe}_{2} \mathrm{O}_{3}$ 含有量が約4 wt.\%である単斜輝石69-27のスペ クトルはかなり劣化する. 

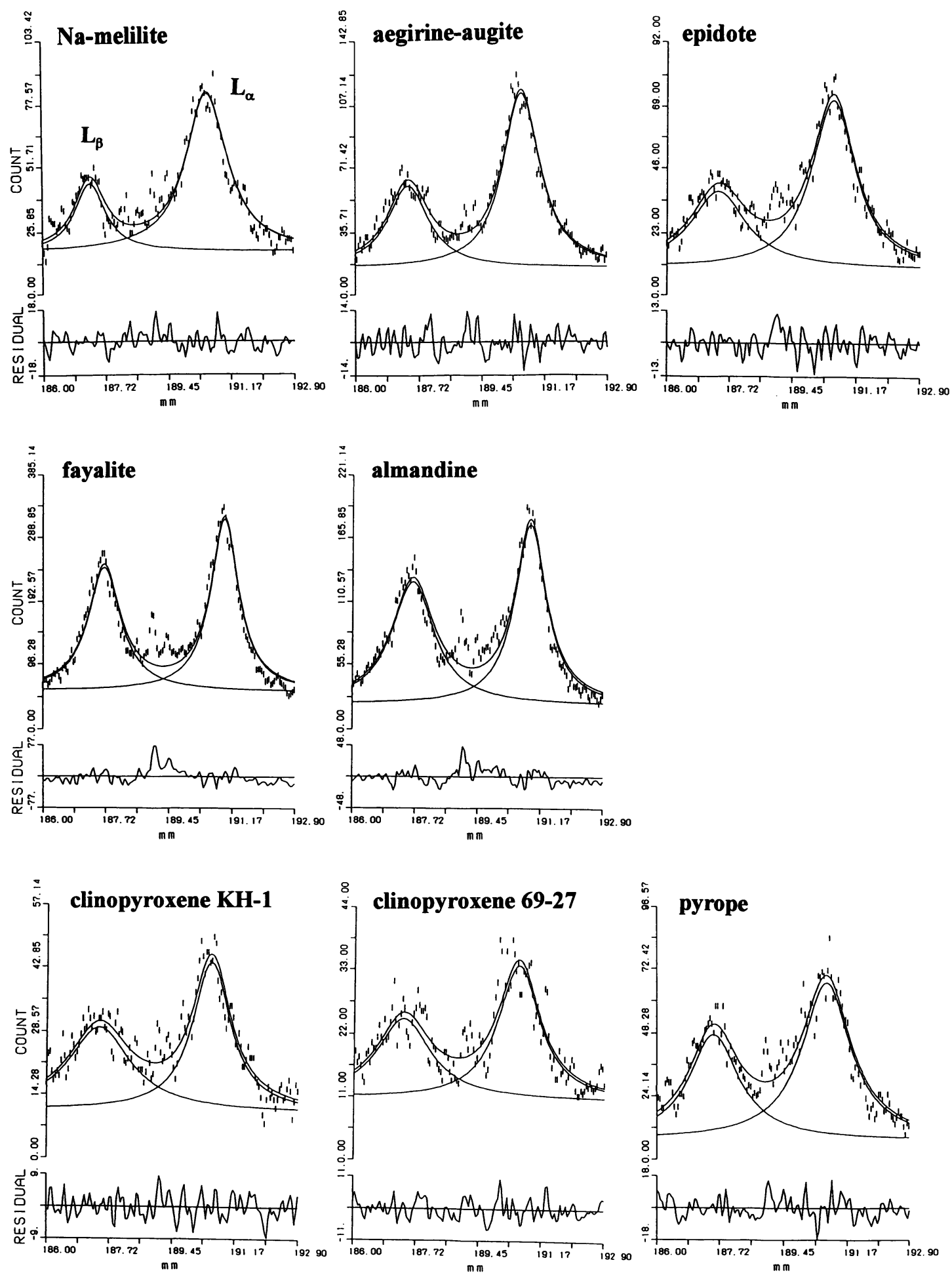

Fig. 1 Microprobe wavelength scans and fitted patterns for $L_{\alpha}$ and $L_{\beta}$ emission peaks of $F e$ and $M n$ in silicates. 

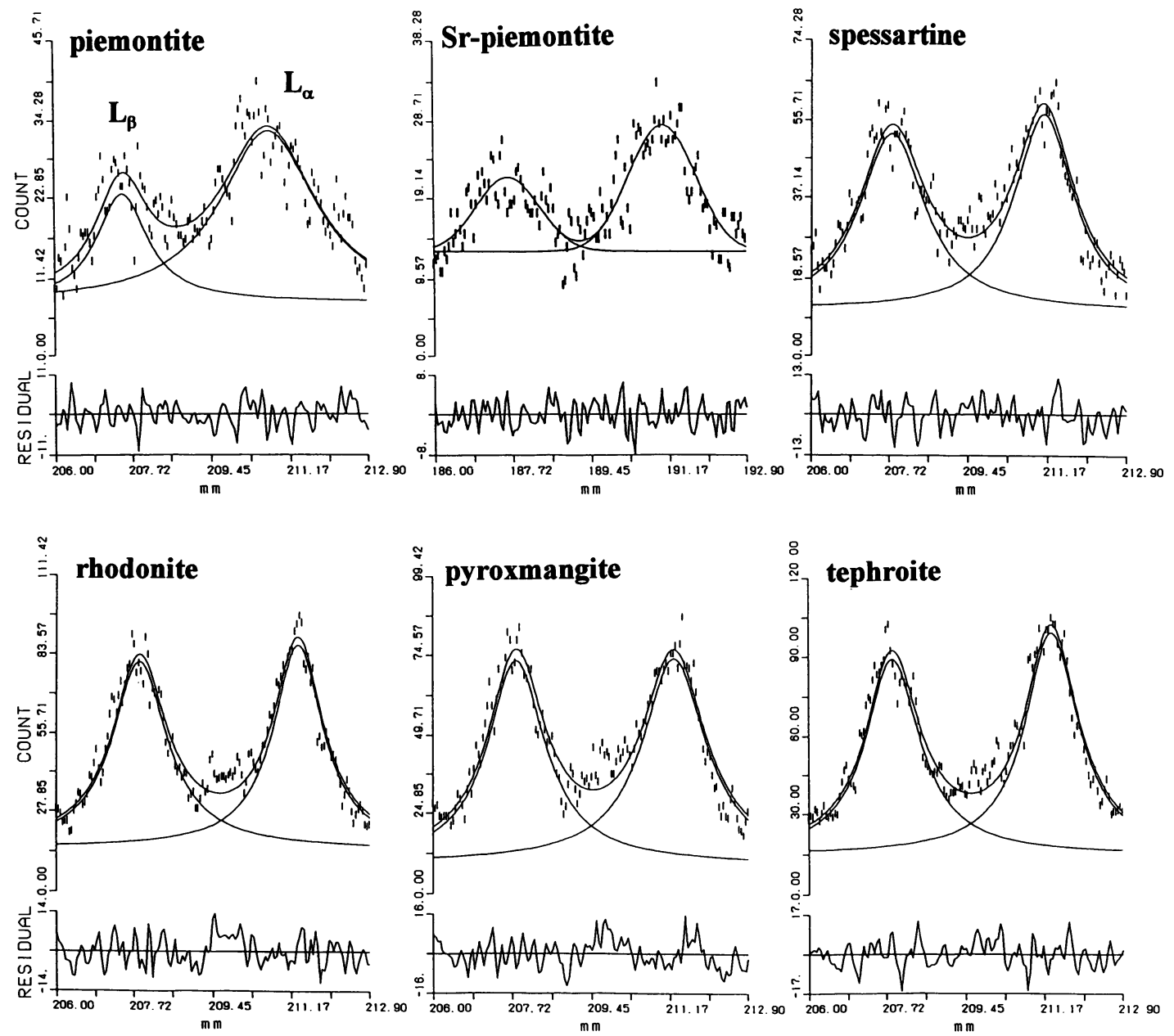

Fig. 1 (Continued)

Table 2 Fitting parameters for $\mathrm{L}_{\alpha}$ and $\mathrm{L}_{\beta}$ emission peaks of $\mathrm{Fe}(\mathrm{A})$ and $\mathrm{Mn}$ (B)

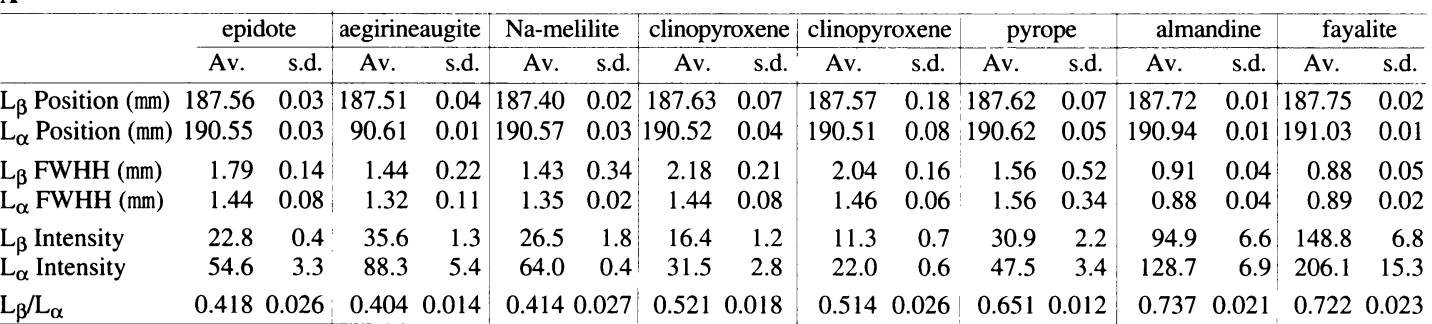

B

$$
\begin{aligned}
& \text { piemontite Sr-piemontite spessartine rodonite pyroxmangite tephroite }
\end{aligned}
$$

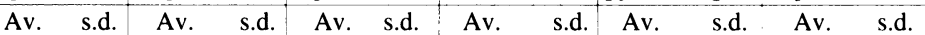

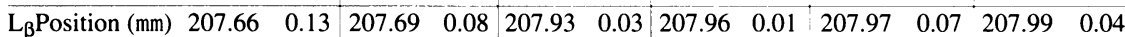

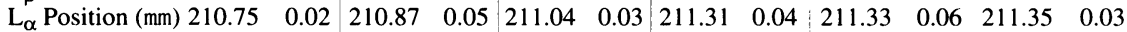

$\begin{array}{lllllllllllll}\mathrm{L}_{\beta} \text { FWHH (mm) } & 1.14 & 0.45 & 1.48 & 0.13 & 1.32 & 0.32 & 1.18 & 0.07 & 1.18 & 0.04 & 1.12 & 0.06\end{array}$

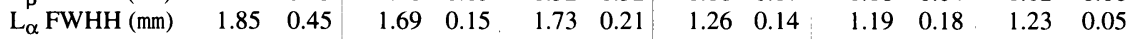

\begin{tabular}{l|l|l|l|l|l|l|l|l|l|l|l|l}
\hline $\mathrm{L}_{\beta}$ Intensity & 9.1 & 3.5 & 10.9 & 1.4 & 32.8 & 3.3 & 50.4 & 1.2 & 43.5 & 5.0 & 55.8 & 1.5 \\
\hline
\end{tabular}

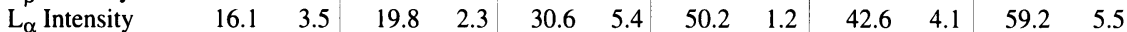

* Standard samples are

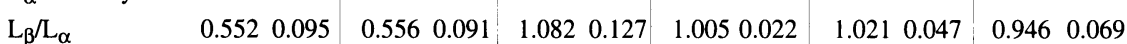
described in Table 1 


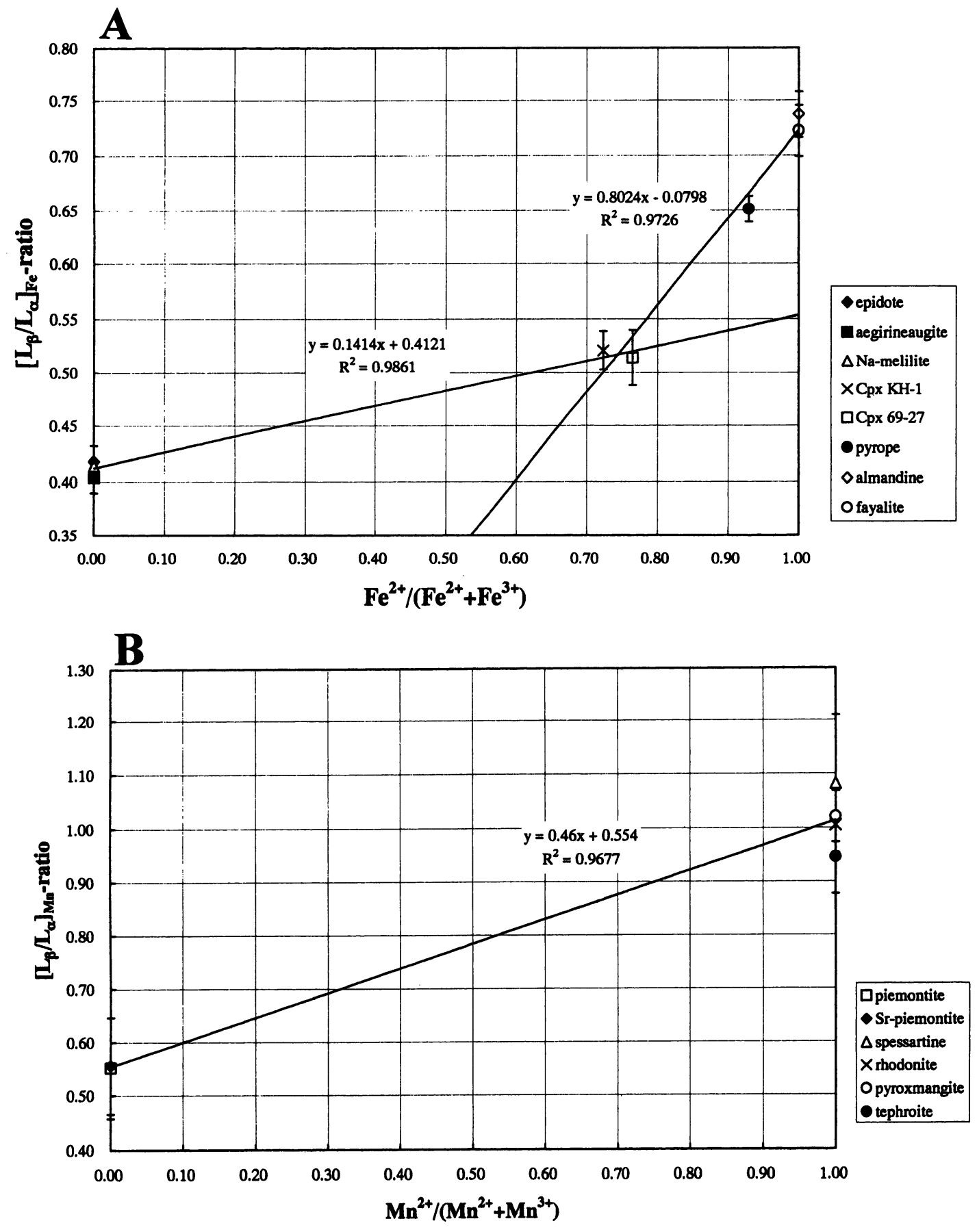

Fig. $2 \mathrm{~L}_{\beta} / \mathrm{L}_{\alpha}$ ratios for silicates of $\mathrm{Fe}(\mathbf{A})$ and $\mathrm{Mn}(\mathbf{B})$

これらの結果を $\mathrm{Fe}^{2+} /\left(\mathrm{Fe}^{2+}+\mathrm{Fe}^{3+}\right)$ 比と $\left[\mathrm{L}_{\beta} / \mathrm{L}_{\alpha}\right]_{\mathrm{Fe}}$ 比の関 係として図示したのがFig. 2Aである. Albee and Chodos $(1970)^{5)}$ では $\mathrm{Fe}^{2+}$ と $\mathrm{Fe}^{3+}$ の両方を含む試料のデータがな
く, 回帰直線で近似していたが, 本研究の結果では少 なくとも回帰直線で相関関係を近似するのは不適当で

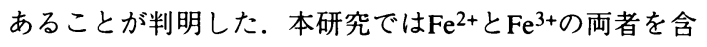


む鉱物の数が限られているため, Fig. 2 Aに示すように, ファヤライト, アルマンディンとパイロープ, 単斜輝石 KH-1, 単斜輝石69-27の間での回帰直線, および 2 種の単 斜輝石KH-1，69-27とNa-メリライト, エジリンオージャ イト，緑䈴石の間での回帰直線によって $\mathrm{Fe}^{2+} /\left(\mathrm{Fe}^{2+}+\mathrm{Fe}^{3+}\right)$ 比と $\left[\mathrm{L}_{\beta} / \mathrm{L}_{\alpha}\right]_{\mathrm{Fe}}$ 比の相関関係を示す；

(1) $0 \leq\left[\mathrm{Fe}^{2+} /\left(\mathrm{Fe}^{2+}+\mathrm{Fe}^{3+}\right)\right] \leq 0.74$ :

$\left[\mathrm{L}_{\beta} / \mathrm{L}_{\alpha}\right]_{\mathrm{Fe}}=0.1414 \times\left[\mathrm{Fe}^{2+} /\left(\mathrm{Fe}^{2+}+\mathrm{Fe}^{3+}\right)\right]+0.4121\left(\mathrm{R}^{2}=0.986\right)$

(2) $0.74 \leq\left[\mathrm{Fe}^{2+} /\left(\mathrm{Fe}^{2+}+\mathrm{Fe}^{3+}\right)\right] \leq 1.00$ :

$\left[\mathrm{L}_{\beta} / \mathrm{L}_{\alpha}\right]_{\mathrm{Fe}}=0.8024 \times\left[\mathrm{Fe}^{2+} /\left(\mathrm{Fe}^{2+}+\mathrm{Fe}^{3+}\right)\right]-0.0798\left(\mathrm{R}^{2}=0.973\right)$.

これらの回帰直線のうち, (2)の勾配が大きく, $\mathrm{Fe}^{2+}$ お

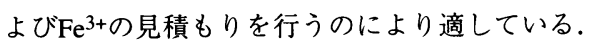

3. $2 \mathrm{Mn}^{2+/}\left(\mathrm{Mn}^{2+}+\mathrm{Mn}^{3+}\right)$ 比と $\left[\mathrm{L}_{\beta} / \mathbf{L}_{\alpha}\right]_{\mathrm{Mn}}$ 比の関係

測定に使用したマンガンケイ酸塩鉱物のスペクトルと フィッティングした結果をFig. 1に，また，解析結果を Table 2Bに示す. バラ輝石, パイロキシマンジャイト, テフロ石の平均total $\mathrm{MnO}$ は, それぞれ48.3 $\pm 1.7 \mathrm{wt} . \%(\mathrm{n}=$ 5), $42.6 \pm 0.5$ wt.\% ( $n=15), 50.4 \pm 0.7$ wt.\% ( $=7)$ である.これ らの鉱物のスペクトルは比較的良好で, $\left[\mathrm{L}_{\beta} / \mathrm{L}_{\alpha}\right]_{\mathrm{Mn}}$ 比は

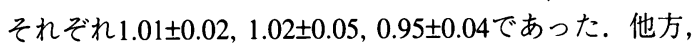
total $\mathrm{Mn}_{2} \mathrm{O}_{3}$ 含有量がそれぞれ16.0 0.7 wt.\% (n=15)および

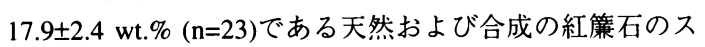
ペクトルはあまり明瞭でなく，スペクトルの測定ごとの ばらつきも大きい. $\left[\mathrm{L}_{\beta} / \mathrm{L}_{\alpha}\right]_{\mathrm{Mn}}$ 比は, $0.55 \pm 0.10,0.56 \pm 0.09$ と誤差内で一致しているが, 標準偏差が大きい. 本研究 で用いた Mnケイ酸塩鉱物には $\mathrm{Mn}^{2+}$ と $\mathrm{Mn}^{3+}$ の両者を含む ものはないので, $\mathrm{Mn}^{2+} /\left(\mathrm{Mn}^{2+}+\mathrm{Mn}^{3+}\right)$ 比が 0.00 と 1.00 の $\left[\mathrm{L}_{\beta} / \mathrm{L}_{\alpha}\right]_{\mathrm{Mn}}$ 比を用いて, $\mathrm{Mn}^{2+} /\left(\mathrm{Mn}^{2+}+\mathrm{Mn}^{3+}\right)$ 比と $\left[\mathrm{L}_{\beta} / \mathrm{L}_{\alpha}\right]_{\mathrm{Mn}}$ 比の関係を回帰直線であらわすと,

$\left[\mathrm{L}_{\beta} / \mathrm{L}_{\alpha}\right]_{\mathrm{Mn}}=0.46 \times\left[\mathrm{Mn}^{2+} /\left(\mathrm{Mn}^{2+}+\mathrm{Mn}^{3+}\right)\right]+0.554\left(\mathrm{R}^{2}=0.968\right)$ という結果となった (Fig. 2 B).

\section{4. 考察とまとめ}

Albee and Chodos $(1970)^{5) の}$ 追試を行った結果, $\mathrm{Fe}^{2+}$ : $\mathrm{Fe}^{3+}$ 比および $\mathrm{Mn}^{2+}: \mathrm{Mn}^{3+}$ 比と $\left[\mathrm{L}_{\beta} / \mathrm{L}_{\alpha}\right]_{\mathrm{Fe}}$ および $\left[\mathrm{L}_{\beta} / \mathrm{L}_{\alpha}\right]_{\mathrm{Mn}}$ の 間に相関関係があることが確認された.しかし, ケイ酸 塩鉱物中のFeについてはAlbee and Chodos $(1970)^{5)}$ が推定 した直線回帰は不適当であることが明らかとなった。 $\mathrm{Fe}^{2+} /\left(\mathrm{Fe}^{2+}+\mathrm{Fe}^{3+}\right)$ 比が75\%以上であれば $3 \%$ 程度の誤差 で $\mathrm{Fe}^{2+} /\left(\mathrm{Fe}^{2+}+\mathrm{Fe}^{3+}\right)$ 比を見積もることが可能であるが, $\mathrm{Fe}^{2+} /\left(\mathrm{Fe}^{2+}+\mathrm{Fe}^{3+}\right)$ 比が75\%以下では $\mathrm{Fe}^{2+} /\left(\mathrm{Fe}^{2+}+\mathrm{Fe}^{3+}\right)$ 比が求 められても誤差が大きく実用上は問題がある.しかし, 他の方法で見積もった $\mathrm{Fe}^{2+} /\left(\mathrm{Fe}^{2+}+\mathrm{Fe}^{3+}\right)$ 比をクロスチェッ クする目的ならば使用可能であろう，例えば, メスバウ アー法によって $\mathrm{Fe}^{2+} /\left(\mathrm{Fe}^{2+}+\mathrm{Fe}^{3+}\right)$ 比が17.6\%と決定された
$\mathrm{Fe}$ パンペリー石(Akasaka et al., 1997) を求め, 上で述べた検量線を用いて $\mathrm{Fe}^{2+} /\left(\mathrm{Fe}^{2+}+\mathrm{Fe}^{3+}\right)$ 比を 求めたところ $15.3 \%$ \%いう值が得られた。ケイ酸塩鉱物 中のtotal FeOが5 wt.\%以上であれば15 kVの加速電圧, $3 \times$ $10^{-8} \mathrm{~A}$ 程度のPCD電流值で良好なスペクトルが測定でき, ピークをフィッティングすることによりピーク強度読み 取りの際の人為的誤差をなくすることができるので, こ こで紹介した方法はケイ酸塩鉱物の $\mathrm{Fe}^{2+} /\left(\mathrm{Fe}^{2+}+\mathrm{Fe}^{3+}\right)$ 比を 見積もる際にやってみる価値があると考える.なお, 本 研究では雲母族鉱物についての追試を行っていないが, Albee and Chodos $(1970)^{5)}$ は雲母族鉱物中の $\mathrm{Fe}^{2+} /\left(\mathrm{Fe}^{2+}+\right.$ $\left.\mathrm{Fe}^{3+}\right)$ 比は $\left[\mathrm{L}_{\beta} / \mathrm{L}_{\alpha}\right]_{\mathrm{Fe}}$ と明瞭な相関を示さないことを明らか にしている。これが雲母族鉱物の結晶構造に関係した不 可避的現象なのか, あるいは加速電圧などの測定条件の 調整によって解決できる問題なのかについては不明であ り，今後の更なる検討が必要である。このような問題が あるので, 対象としている鉱物にこの方法を適用する際 には，適当な標準試料を準備して測定条件と測定結果の 検討を行っておく必要がある。

Mnケイ酸塩鉱物については, 今回の測定条件ではMn 含有量がtotal $\mathrm{MnO}$ として10 wt.\%以上でなければ明瞭な スペクトルが測定できず，かつ，測定毎のばらつきが大 きい.さらに, $\mathrm{Mn}^{2+}: \mathrm{Mn}^{3+}$ 比が中間付近の試料に関する $\left[\mathrm{L}_{\beta} / \mathrm{L}_{\alpha}\right]_{\mathrm{Mn}}$ 比のデー夕もないので, 現時点ではAlbee and Chodos $(1970)^{5)}$ の方法で $\mathrm{Mn}^{2+}: \mathrm{Mn}^{3+}$ 比を見積もるのは難 しい. しかし，この限界を認識した上で使用すれば有益 な情報をもたらしてくれるであろう。たとえば，示差熱 分析法で含水量を，また，メスバウアー法で $\mathrm{Fe}$ の酸化数 を決定し，チャージバランスから $\mathrm{Mn}^{2+} /\left(\mathrm{Mn}^{2+}+\mathrm{Mn}^{3+}\right)$ を26 \%と推定したオホーツク石(木村ほか，19963) ; Akasaka et al., 19974) $)$ にいて, $\left[\mathrm{L}_{\beta} / \mathrm{L}_{\alpha}\right]_{\mathrm{Mn}}$ から推定した $\mathrm{Mn}^{2+1}$ $\left(\mathrm{Mn}^{2+}+\mathrm{Mn}^{3+}\right)$ は40 \%であった. したがって，少なくとも このオホーツク石には $\mathrm{Mn}^{3+た ゙ け て ゙ な く ~} \mathrm{Mn}^{2+}$ 存在する ことは間違いない.

鉄酸化物については, 磁鉄鉱と赤鉄鉱を測定したのみ で, Albee and Chodos (1970) $)^{5)}$, Smith and O'Nions (1971 $)^{6)}$, O'Nions and Smith (1971) $)^{7)}$ らの研究ほど系統的な検討を 行っていないので紹介を控える．しかし，磁鉄鉱を薬品 処理した際の表面上の $\mathrm{Fe}^{2+}$ 濃度変化を $\left[\mathrm{L}_{\beta} / \mathrm{L}_{\alpha}\right]_{\mathrm{Fe}}$ 比によ って検出できたことから，鉄酸化物の場合にも目的に応 じてこの方法を活用できると考える.

この方法は労多くして実りが少ないと感じた方も多い かと思われる.しかし，最初に述べたように遷移元素の 酸化数を見積もるためのいくつか方法は，一長一短があ って，ひとつで万能というわけには行かず，今後もいろ 
いろな方法の開発が行われるであろう．EPMAは現在で はどこの大学にもあるし, 点分析した部分のFeや Mnの 酸化数を見積もることができる可能性があるのだから， 測定条件や標準試料の検討，あるいはこの方法の有効性 と限界の検討をさらに行うべきであると考える。

謝辞：本論を書く機会を与えてくださった新潟大学 赤 井純治氏に感謝します．分析に使用したEPMA用標準試 料の一部を提供してくださいました八木健三 北海道大 学名誉教授, 本研究に有益なご助言をくださいました信 州大学 山口佳昭氏, 同 牧野州明氏, 九州大学 進野 勇 氏, 無機材質研究所 大橋晴夫氏, および本論を査読し てくださいました查読者に深く感謝いたします.

\section{文献}

1) Togari, K. and Akasaka, M. (1987): Okhotskite, a new mineral, an $\mathrm{Mn}^{3+}$-dominant member of the pumpellyite group, from the Kokuriki mine, Hokkaido, Japan. Mineral. Mag., 51, 611-614.

2) Togari, K., Akasaka, M., Sakakibara, M. and Watanabe, T. (1988): Mineralogy of manganiferous iron ore deposits and chert from the Tokoro Belt, Hokkaido. Mining Geol. Special Issue, 12, 115-126.

3）木村佳央 - 赤坂正秀 - 榊原正幸 - 進野 勇 - 口茠賢二 (1995)：オホーツク石における $\mathrm{Fe}^{3+}$ および $\mathrm{Mn}^{3+}$ の席選 択性. 島根大学地質学研究報告, 14, 43-54.

4) Akasaka, M., Kimura, Y., Omori, Y., Sakakibara, M., Shinno, I. And Togari, K. (1997): 57Fe Mossbauer study of pumpellyite-okhotskite-julgoldite series minerals. Mineral. Petrol., 61, 181-198.
5) Albee, A. L. and Chodos, A. A. (1970): Semiquantitative electron microprobe determination of $\mathrm{Fe}^{2+} / \mathrm{Fe}^{3+}$ and $\mathrm{Mn}^{2+} / \mathrm{Mn}^{3+}$ in oxides and silicates and its application to petrologic problems. Am. Mineral., 55, 491-501.

6) Smith, D. G. W. and O'Nions, R. K. (1971): Investigations of the Fe $L_{\text {IIIIIII }} \mathrm{X}$-ray emission spectra of Fe by the electron microprobe. Part 1. Some aspects of the Fe $L_{\mathrm{II}, \mathrm{III}}$ spectra from metallic iron and hematite. Brit. J. Appl. Phys., 4, 147-159.

7) O'Nions, R. K. and Smith, D. G. W. (1971): Investigations of the Fe $L_{\mathrm{II}, \mathrm{III}} \mathrm{X}$-ray emission spectra of $\mathrm{Fe}$ by the electron microprobe. Part 2. The Fe $L_{\mathrm{IIIIII}}$ spectra of $\mathrm{Fe}$ and FeTi oxides. Am. Mineral., 56, 1452-1463.

8) Akasaka, M. and Ohashi, H. (1985): ${ }^{57} \mathrm{Fe}$ Mössbauer study of synthetic $\mathrm{Fe}^{3+}$-melilites. Phy. Chem. Minerals, 12, 13-18.

9) Katsushima, T. and Yanai, K. (1984): Geology of several islands of the west of Langhovde, east Antarctica. Mem. National Inst. Polar Research Special Issue, 33, 155-168.

10) Akasaka, M., Sakakibara, M. and Togari, K. (1988): Piemontite from the manganiferous hematite ore deposits in the Tokoro belt, Hokkaido, Japan. Mineral. Petrol., 38, $105-116$

11) 鈴木やよい・赤坂正秀·Zheng Yuanyuan (1996)：紅策 石におけるSr最大固溶量. 日本鉱物学会1996年年会講 演要旨集, pp24.

12) 渡辺弘明・赤坂正秀(1995)：鳥取県東部層状マンガン鉱 床に抄ける接触変成と熱水作用による釷石鉱物と脈石 鉱物. 資源地質学会・日本岩石鉱物鉱床学会・日本鉱 物学会 平成 7 年度秋季連合学術講演会講演要旨集, pp. 138 . 